\title{
Socioeconomic Status and Its Effects on Higher Education Opportunity: The Case of Greece
}

\author{
Marilou Ioakimidis $^{1,2}$, George Papakonstantinou ${ }^{2}$ \\ ${ }^{1}$ University of Peloponnese, Peloponnese, Greece \\ ${ }^{2}$ National and Kapodistrian University of Athens, Athens, Greece \\ Email: mioakeim@econ.uoa.gr, marilou@uop.gr
}

How to cite this paper: Ioakimidis, M. and Papakonstantinou, G. (2017) Socioeconomic Status and Its Effects on Higher Education Opportunity: The Case of Greece. Theoretical Economics Letters, 7, 1761-1769. https://doi.org/10.4236/tel.2017.76119

Received: September 18, 2017

Accepted: October 16, 2017

Published: October 19, 2017

Copyright ( 92017 by authors and Scientific Research Publishing Inc. This work is licensed under the Creative Commons Attribution-NonCommercial International License (CC BY-NC 4.0). http://creativecommons.org/licenses/by-nc/4.0/ (c) (i) \&) Open Access

\begin{abstract}
Gaining access to higher education theoretically enables social mobility for students from lower socioeconomic classes but students from lower-income, working class families are much less likely to attend university. Data from a sample survey of over 2000 Greek university freshmen were analyzed using multiple linear regression analysis to identify factors influencing the affordability of a first-year university education in Greece. Results showed that family income is the strongest predictor of the affordability of higher education in Greece and that a university education is substantially more affordable for the upper socioeconomic or management classes in Greece compared to that for working class families. This finding partially explains why families from the upper socioeconomic strata in Greece invest the most in preparing their children for university admission. This also helps explain why approximately $80 \%$ of the first-year university slots are occupied by "management class" families. While the average Greek family invests almost half of their annual income to support a child's university education, the families of working class families sacrifice almost $60 \%$ of their annual income to achieve the same goal, something they can much less afford to do. It should come as no surprise then that the children of working class families occupy only one in five classroom seats in the Greek system of higher education. More research is needed to understand the underlying causes of this disparity. Alternatively, more can be done from a social policy perspective to help promising low-income secondary students become better prepared academically for pursuing and applying to institutions of higher education in Greece.
\end{abstract}

\section{Keywords}

University Costs, Family Income and Expenditures, Social Mobility 


\section{Introduction}

While participation in higher education in Greece has increased in recent years, this has been shaped to a large degree by the widening socioeconomic disparities in Greek society which favor the privileged social classes [1] [2]. Gaining access to higher education enables social mobility for students from lower socioeconomic classes but the irony is that students from lower-income families are much less likely to attend college [3]. This is true in much of the developed world as well as in Greece. In the United States, England, and Australia, for example, higher education participation rates are generally much higher for children of professional and upper income families compared with those of working class and lower income homes [4] [5] [6]. In short, participation in higher education is more concentrated among upper socioeconomic families.

Merit also plays a role in determining access to higher education. In Greece, university admission is determined by scores on the nationwide Panhellenic exams. While a university education is tuition-free in Greece, there are substantial private costs associated with preparing secondary students for the university entrance exams. Greece has an ancillary system of secondary education that families use to help prepare their children for the Panhellenic exams. This system involves a network of private prep schools (referred to as frontisteria), private tutors, and private Lyceum at the upper secondary level [7] [8]. The ancillary education system tends to benefit the students of the privileged social classes more than the children of lower socioeconomic families, thus perpetuating the preexisting social inequities in Greece [1]. Additionally, families must cover their children's living expenses while enrolled in higher education.

\section{Study Focus and Methodology}

This paper uses data from a sample survey of Greek university freshmen that measured family costs associated with preparing their children for the university entrance examinations as well as the costs of living associated with first-year university attendance. The analysis reported in this paper shows how entrance examination preparation costs and university attendance costs tend to be stratified by socioeconomic factors such as family income, father's occupation and father's education. A key feature of the analysis is an indicator of "financial sacrifice" that shows the percentage of a family's annual income necessary for covering the total costs of a first-year university education in Greece. Tables are presented showing the breakdown of entrance exam preparation costs and university attendance costs by father's occupation. A similar set of tables are presented showing how family sacrifice varies by fathers' occupation and education levels. Finally, the results of a multiple linear regression analysis show how five factors affect the affordability of a first-year university education in Greece.

The survey was randomly distributed to 2.370 freshmen students in 58 departments across seven major Greek universities in the spring of 2014. On average, $18 \%$ of the students in each department returned the survey for a total anal- 
ysis sample of 2235 students (see Table S1 in Appendix). The survey achieved a return rate of $94 \%$ (in the majority of the questions). Key variable definitions can be found in Table S2.

\section{The Costs of Higher Education in Greece}

Secondary school students in Greece start preparing for the university entrance exams years in advance. Families do this by sending their children to private prep schools and private Lyceums and/or by hiring private tutors. These costs are shown in Table 1. Almost half the sample (48.9\%) attended the "frontisteria" prep schools, $14.2 \%$ of the sample engaged private tutors, and approximately one third of the sample did both. Approximately $10 \%$ of the sample attended a private Lyceum. Most often (48\% of the time), students were enrolled in the "frontisteria" private prep schools for two years before taking the national university entrance exams. Private tutors were most often (39\% of the time) hired for one year.

The data in Table 1 suggest that families with the highest incomes (fathers with executive occupations) invest the most in preparing their children for the university entrance exams. They do so by availing themselves of all three means of university preparation: prep schools, private tutors, and private schools. Overall, it is the executive and white-collar families that spend the most in preparing their children for the national Panhellenic exams.

Once a student enters the Greek higher education system, tuition is free but the costs of attending university must be borne by the student and his/her family. These costs are shown in Table 2 . The total annualized cost of university attendance paid by students and their families is approximately equal to the per-pupil cost for tuition paid by the state [8]. A major cost component of university attendance is paying rent.

\section{Family Economic Sacrifice}

Greek families at all levels of society invest a substantial portion of their income

Table 1. Annualized Mean Costs (in Euros) for University Preparation by Father's Occupation.

\begin{tabular}{cccccc}
\hline $\begin{array}{c}\text { Father's } \\
\text { Occupation }\end{array}$ & $\begin{array}{c}\text { Sample } \\
\text { Size } \\
\mathrm{N}\end{array}$ & $\begin{array}{c}\text { Cost }(€) \text { of } \\
\text { Frontisteria } \\
\text { Private Prep } \\
\text { Schools }\end{array}$ & $\begin{array}{c}\text { Cost }(€) \text { of Private } \\
\text { Lessons/ } \\
\text { Tutoring }\end{array}$ & $\begin{array}{c}\text { Cost }(€) \text { of } \\
\text { Private Lyceum } \\
\text { Schools }\end{array}$ & $\begin{array}{c}\text { Total } \\
\text { Preparation } \\
\text { Costs }(€)\end{array}$ \\
\hline Executive & 402 & 2359 & 3234 & 7090 & 12,683 \\
White Collar & 1476 & 2807 & 1754 & 3036 & 7597 \\
Farmer - Fisher & 124 & 2926 & 1681 & 0 & 4607 \\
Blue Collar & 119 & 2473 & 1183 & 1573 & 5229 \\
Unskilled & 69 & 2868 & 996 & 0 & 3864 \\
Total & 2190 & $(2686)^{\mathrm{a}}$ & $(1770)$ & $(2340)$ & $(6796)$ \\
\hline
\end{tabular}

a. In parenthesis: mean cost for each category. 
Table 2. Annualized Mean Costs (in Euros) of University Attendance by Father's Occupation.

\begin{tabular}{ccccccccc}
\hline $\begin{array}{c}\text { Father's } \\
\text { Occupation }\end{array}$ & $\begin{array}{c}\text { Sample } \\
\text { Size }\end{array}$ & $\begin{array}{c}\text { Rent } \\
\text { Costs } \\
(€)\end{array}$ & $\begin{array}{c}\text { Food } \\
\text { Costs } \\
(€)\end{array}$ & $\begin{array}{c}\text { Local } \\
\text { Transportation } \\
\text { Costs }(€)\end{array}$ & $\begin{array}{c}\text { Book } \\
\text { Costs } \\
(€)\end{array}$ & $\begin{array}{c}\text { Personal } \\
\text { Expenses } \\
(€)\end{array}$ & $\begin{array}{c}\text { Travel } \\
\text { Home } \\
(€)\end{array}$ & $\begin{array}{c}\text { Total } \\
\text { Costs } \\
(€)\end{array}$ \\
\hline Executive & 402 & 1424 & 858 & 252 & 230 & 827 & 162 & 3753 \\
White Collar & 1476 & 1412 & 739 & 246 & 180 & 763 & 155 & 3495 \\
Farmer - & 124 & 2230 & 954 & 253 & 174 & 826 & 328 & 4765 \\
Fisher & 119 & 1368 & 725 & 281 & 144 & 731 & 138 & 3387 \\
Blue Collar & 69 & 1365 & 718 & 193 & 175 & 583 & 168 & 3202 \\
Unskilled & 2190 & $(1560)^{\mathrm{a}}$ & $(798)$ & $(245)$ & $(181)$ & $(746)$ & $(190)$ & $(3720)$ \\
Total & & & & & & & & \\
\hline
\end{tabular}

a. In parenthesis: mean cost for each category.

Table 3. Percent of Family Income to Cover Higher Education Costs by Father's Occupation.

\begin{tabular}{ccccc}
\hline Father's Occupation & $\begin{array}{c}\text { Sample Size } \\
\mathrm{N}\end{array}$ & $\begin{array}{c}\text { Total Costs } \\
\text { per Year }(€)\end{array}$ & $\begin{array}{c}\text { Family Income } \\
\text { per Year }(€)\end{array}$ & Family Sacrifice \% $^{\mathrm{b}}$ \\
\hline Executive & 402 & 16,436 & 38,774 & 42.39 \\
White Collar & 1476 & 11,092 & 25,543 & 43.42 \\
Farmer - Fisher & 124 & 9372 & 14,510 & 64.59 \\
Blue Collar & 119 & 8616 & 16,471 & 52.31 \\
Unskilled & 69 & 7066 & 11,168 & 63.27 \\
Total & 2190 & $(10,516)^{\mathrm{a}}$ & $(21,293)$ & 49.38 \\
\hline
\end{tabular}

a. In parenthesis: mean cost for each category; b. Sacrifice $=($ Total Annual Costs/Annual Family Income $) \times$ 100 .

in supporting their children's aspirations for a university education. As shown by the total "sacrifice" estimate in Table 3, the average Greek family in the study sample invested nearly $50 \%$ of their annual family income to cover the total costs of a university education for their child. This includes both the cost of preparing for the nationwide university entrance exams as well as living and study expenses once admitted to a university.

An important take-away from the data in Table 3 is that a university education is more affordable for the higher income segments of Greek society. Specifically, the executive and white-collar families in the sample spent approximately $43 \%$ of their income to support their children's efforts to attain a university education whereas the working-class families ${ }^{1}$ in the sample spent approximately $60 \%$ of their income to achieve the same objective.

A similar analysis was carried out with father's education, as shown in Table 4. In this analysis, it is clear that higher education in Greece is most affordable

${ }^{1}$ Working-class families, fathers' occupations category included: farmers and fishermen, blue-collar workers, and unskilled laborers. 
Table 4. Percent of Family Income to Cover Higher Education Costs by Father's Education.

\begin{tabular}{ccccc}
\hline Father's Education & $\begin{array}{c}\text { Sample Size } \\
\text { N }\end{array}$ & $\begin{array}{c}\text { Total Costs } \\
\text { per Year }(€)\end{array}$ & $\begin{array}{c}\text { Family Income } \\
\text { per Year }(€)\end{array}$ & Family Sacrifice \% $^{\mathrm{b}}$ \\
\hline University & 719 & 12,670 & 31,651 & 40.03 \\
Technical School & 298 & 11,383 & 21,692 & 52.48 \\
Lyceum & 405 & 11,515 & 23,592 & 48.81 \\
High School & 144 & 10,570 & 18,184 & 58.13 \\
Primary School & 142 & 8785 & 16,550 & 53.08 \\
Total & $1708^{2}$ & $(10,985)^{\mathrm{a}}$ & $(22,334)$ & 49.18 \\
\hline
\end{tabular}

a. In parenthesis: mean cost for each category; b. Sacrifice $=($ Total Annual Costs/Annual Family Income $) \times$ 100.

Table 5. Summary of Regression Analysis: Variables Predicting Affordability of Higher Education in Greece $(\mathrm{N}=1741)$.

\begin{tabular}{cccccc}
\hline Variable & B & SE B & Beta & Zero-order Correlations & Partial Correlations \\
\hline Constant & 1.82 & 0.02 & & & \\
Family Income & -8.08 & 0.00 & $-0.54^{* *}$ & -0.53 & -0.53 \\
Management Class & -0.07 & 0.02 & $-0.09^{* *}$ & -0.20 & -0.10 \\
University Educated & -0.05 & 0.01 & $-0.08^{* *}$ & -0.18 & -0.09 \\
Science Major & 0.03 & 0.01 & $0.05^{*}$ & 0.02 & 0.06 \\
Private School & 0.26 & 0.02 & $0.23^{* *}$ & 0.10 & 0.26 \\
\hline
\end{tabular}

Note. Adjusted $\mathrm{R}^{2}=0.33 ;{ }^{* *} \mathrm{p}<0.01 ;{ }^{*} \mathrm{p}<0.05$.

for families of a university-educated father and less so otherwise. The fact that access to higher education in Greece is easier for the socioeconomically privileged, raises issues of social justice and inequalities [9].

\section{The Affordability of Higher Education in Greece}

We viewed the "sacrifice" metric as an indicator of the affordability of higher education in Greece. Our interest was in determining the predictors of higher education affordability and multiple linear regression analysis was used toward this end. A log transformation of the response variable "sacrifice" was conducted to remedy a degree of non-constant variance in the data [10]. The improved model is shown in Table 5 .

The data in Table 5 show that annual family income is the strongest predictor of the affordability of higher education in Greece. The greater the family's income, the more affordable higher education is in Greece. Correspondingly, higher education is more affordable for the upper socio-economic classes in Greece. For example, the data in Table 5 suggest that, on the average, higher education is about $7 \%$ more affordable for families from executive and white

${ }^{2}$ The sample distribution and the total No differs from that reported in other tables due to limited replied in the related questions. 
collar occupations compared to working class families. Similarly, higher education tends to be about $5 \%$ more affordable for families with university-educated fathers compared to families whose fathers have lower levels of education. As a related matter, the results of the nationwide university entrance exam favor the children of management class families ( $\mathrm{d}=675$ points) and university-educated fathers ( $d=440$ points) compared to the children of working class families and non-university educated fathers.

Alternatively, higher education in Greece is about 3\% more expensive for families whose children pursue science majors compared to the humanities or technology fields of study. Additionally, the data in Table 5 suggest that Greek families who send their children to private secondary schools (Lyceum) to prepare them for college adds about $26 \%$ to the cost of a university education. While the test score sample is limited $(\mathrm{N}=132)$, this investment apparently pays off since university entrance exam results substantially favor the graduates of private secondary schools in Greece over public school graduates (mean difference $=836$ points; $\mathrm{t}=5.99, \mathrm{df}=100.46, \mathrm{p}<0.01)$.

\section{Discussion and Conclusions}

The study's overall survey sample $(\mathrm{N}=2370)$ suggests that approximately $79 \%$ of the students in the 2013-2014 Greek university freshman class came from management class families whereas only about $21 \%$ came from working class families ${ }^{3}$. This demographic profile fits the main findings of the study, which is that management class families-those with the highest incomes-tend to invest the most in preparing their children for university admission. By virtue of their higher incomes, these families are also the ones who can most easily afford to invest in their children's educational future.

Since Greek working class families sacrifice more than half of their income (actually about $60 \%$ on the average) when choosing to pursue a university education, is it any wonder that only about $20 \%$ of lower SES families in Greece pursue higher education? The Western ideal is that higher education promotes social mobility. However, some would argue that this is a myth since college attendance is largely pre-determined by socioeconomic factors like family income and parental education.

Bruenig [11] assessed the degree of educational mobility among the 28 OECD countries by asking "How much more likely is a child of highly educated parents to attend college than a child of lowly educated parents?" Results showed that Greece was one of the lowest in educational mobility, ranking $23^{\text {rd }}$ of 28 OECD countries. Specifically, Bruenig found that Greek children of highly educated parents are over five times more likely to attend college than children of lowly educated parents [11].

Why is there such a disparity in how high and low socioeconomic status (SES) families are represented in the Greek system of higher education? Two hypo-

${ }^{3}$ This statistic varies somewhat depending on the specific analysis sample. 
theses have been suggested in the United States to explain the concentration of high SES students in American universities, particularly the more selective ones. First, it has been suggested that low-income students are underprepared academically [12], and second, that low-income students are not applying to selective universities for which they are qualified [13].

The present study has limited data to support the first hypothesis, which is that university entrance exam results favor:

- the graduates of private Greek secondary schools over public schools;

- the children of management class families over working class families; and

- the children of university-educated fathers over non-college graduates.

We also showed that it is the higher income, management class families that invest the most in preparing their children for university entrance. However, we have no data on the second hypothesis, but it is certainly possible that many high-achieving students from working class families in Greece simply do not apply to universities they are qualified for. In the United States, Koffman and Tienda [14] found that students from affluent secondary schools were more likely to apply for university admission than the graduates of low to moderate SES secondary schools.

Policy implications from the Koffman and Tienda [14] study include:

- the need to make college prep programs and tutoring more available to working class families through government subsidies and grant awards to high achieving, low-income students, and

- the need to target university recruitment of talented students from resource poor secondary schools.

\section{References}

[1] Sianou-Kyrgiou, E. (2010) Stratification in Higher Education, Choice and Social Inequalities in Greece. Higher Education Quarterly, 64, 22-40. https://doi.org/10.1111/j.1468-2273.2009.00427.x

[2] Themelis, S. (2013) Social Change and Education in Greece: A Study in Class Struggle Dynamics. Palgrave Macmillan, New York. https://doi.org/10.1057/9781137108616

[3] Hill, C.B. (2015) Income Inequality and Higher Education. http://www.acenet.edu/the-presidency/columns-and-features/Pages/Income-Inequa lity-and-Higher-Education.aspx

[4] Paton, G. (2013) Access to Top Universities "Still Linked to Family Income". Telegraph Media Group.

http://www.telegraph.co.uk/education/universityeducation/10444863/Access-to-top -universities-still-linked-to-family-income.html

[5] Pell Institute (2015) 2015 Indicators of Higher Education Equity. http://www.pellinstitute.org/

[6] Ross, T., Kena, G., Rathbun, A., Kewal Ramani, A., Zhang, J., Kristapovich, P. and Manning, E. (2012) Higher Education: Gaps in Access and Persistence Study. (NCES 2012-046). U.S. Department of Education, National Center for Education Statistics. Government Printing Office, Washington DC. 
[7] Kostakis, A. (1990) Vocational and Academic Secondary Education in Greece: Public and Private Costs Compared. Economics of Education Review, 9, 395-399. https://doi.org/10.1016/0272-7757(90)90021-V

[8] Psacharopoulos, G. and Papakonstantinou, G. (2005) The Real University Cost in a "Free" Higher Education Country. Economics of Education Review, 24, 103-108. https://doi.org/10.1016/j.econedurev.2004.01.003

[9] Symeonaki, M.A. and Stamatopoulou, G.A. (2014) Exploring the Transition to Higher Education in Greece: Issues of Intergenerational Educational Mobility. Policy Futures in Education, 12, 681-694. https://doi.org/10.2304/pfie.2014.12.5.681

[10] Weisberg, S. (1985) Applied Linear Regression. 2nd Edition. John Wiley \& Sons, New York.

[11] Bruenig, M. (2014) Where Is Educational Mobility the Highest? http://www.demos.org/blog/12/28/14/where-educational-mobility-highest

[12] Haycock, K., Lynch, M. and Engle, J. (2010) Opportunity Adrift: Our Flagship Universities are Straying from their Public Mission. The Education Trust, Washington DC. http://files.eric.ed.gov/fulltext/ED507851.pdf

[13] Hoxby, C.M. and Avery, C. (2013) The Missing "One-Offs": The Hidden Supply of High-Achieving, Low-Income Students. Brookings Papers on Economic Activity, 1, 1-65. https://doi.org/10.1353/eca.2013.0000

[14] Koffman, D. and Tienda, M. (2008) Missing in Application: The Texas Top 10\% Law and Campus Socioeconomic Diversity. Paper Presented at the Annual Meetings of the American Educational Research Association, New York City, NY. 


\section{Appendix}

Table S1. Sample Distribution.

\begin{tabular}{cc}
\hline University & Number of Students in the Sample \\
\hline National Kapodistrian University of Athens & 471 \\
University of Thessaloniki & 447 \\
National Technical University of Athens & 139 \\
University of Patras & 389 \\
University of Ioannina & 428 \\
University of Crete & 318 \\
University of the Aegean & 43 \\
Total & 2235
\end{tabular}

Table S2. Key Variable Definitions.

\begin{tabular}{cl}
\hline Variables & \multicolumn{1}{c}{ Definitions } \\
\hline Total Education Costs ${ }^{\text {a }}$ & University Preparation Costs + University Attendance Costs \\
Annual Family Income & Monthly Family Income $\times 12$ \\
Management Class & Father Occupation $=$ Executive or White Collar vs Working Class \\
Working Class & Father Occupation $=$ Farmer/Fisher, Blue Collar or Unskilled vs \\
University Educated & Management Class \\
Science Major & Science Program of Study vs. Humanities or Technology \\
Private School & Private Lyceum vs. Public Lyceum \\
Family Sacrifice $\%$ & (Total Annual Costs/Annual Family Income $\times 100$ \\
\hline
\end{tabular}

a. Education costs were computed on a 10 -month basis. 